


\section{3ngersall Ilectures on 3mmortality}

Imaortality aNd the New Theodicy. By George A. Gordon. 1806 .

Homan Immortality. Two supposed Objections to the Doctrine. By William James. I897.

Dronysos AND Immortality: The Greek Faith in Immortality as affected by the rise of Individualism. By Benjamin Ide Wheeler. 5898 .

The Conception of Immortality. By Josiah Royce. I899.

Life Evernasting. By John Fiske. I000.

Science and Imorortality. By William Osler. 1904.

The Endress LrFe. By Samuel M. Crothers. 1905.

INDIVIDUALTTY AND IMMORTALITY. By Wilhelm Ostwald. rgo6.

The Hope of Immortality. By Charles F. Dole. 1907.

BudDhisy and Immortaurty. By William $S$. Bigelow. I908.

Is Immortaltiy Desirable? By G. Lowes Dickinson. Igog.

Egyptan Conceptions of Imogoradity. By George A. Reisner. 1911 .

INTIMATIONS OF IMMORTALITY IN THE SONNETS of Shakespeare. By George H. Palmer. rgr2.

Metexpsychosis. By George Foot Moore. 1914.

Pagan Ideas of Immortality During the Early Roman EMPIRE. By Clifford Herschel Moore. ro18.

Livmg Agan. By Charles Reynolds Brown. I920.

Irmortality and Theism. By William Wallace Fenn. 1921.

IMMrORTALITY AND THE MODERN MIND. By Kirsopp Lake. 1922.

The Christuan Faith and Etrranal Life. By George E. Horr. 1923.

The Sense of Immortality. By Philip Cabot. 1924.

IMMORTatITy IN POST-KantIan IDEaIISM. By Edgar S. Brightman. I925.

The ImMortality of MaN. By Gustav Krüger. I926.

Spiritual Values and Eternal. LIFe. By Hatry Emerson Fosdick. 1927.

The Meaning of Selfhood and FatTh in ImmorIALITY. By Eugene William Lyman. I928. 


\section{MAN'S CONSCIOUSNESS \\ OF IMMORTALITY}


LONDON : HUMPHREY MILFORD OXFORD UNIVERSITY PRESS 
Tbe Ingergoll Lecture, 1929

\title{
MAN'S CONSCIOUSNESS OF IMMORTALITY
}

\author{
BY \\ W. DOUGLAS MACKENZIE, D.D., LL.D. \\ President, Hartford Seminary Foundation
}

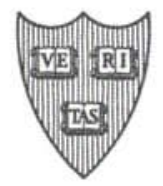

CAMBRIDGE

HARVARD UNIVERSITY PRESS

1929 
COPYRIGHT, I929

BY THE PRESIDENT AND FELLOWS OF HARVARD COLLEGE

PRINTED AT THE HARVARD UNIVERSITY PRESS

Cambridge, Mass., U. S. A. 


\section{THE INGERSOLL LECTURESHIP}

\section{Extract from the will of Miss Caroline Haskell Ingersoll, who died in Keene, County of Cheshire, New Hampshire, Jan. $26,{ }_{1} 883$}

First. In carrying out the wishes of my late beloved father, George Goldthwait Ingersoll, as declared by him in his last will and testament, I give and bequeath to Harvard University in Cambridge, Mass., where my late father was graduated, and which he always held in love and honor, the sum of Five thousand dollars $(\$ 5, \infty)$ as a fund for the establishment of a Lectureship on a plan somewhat similar to that of the Dudleian lecture, that is - one lecture to be delivered each year, on any convenient day between the last day of May and the first day of December, on this subject, "the Immortality of Man," said lecture not to form a part of the usual college course, nor to be delivered by any Professor or Tutor as part of his usual routine of instruction, though any such Professor or Tutor may be appointed to such service. The choice of said lecturer is not to be limited to any one religious denomination, nor to any one profession, but may be that of either clergyman or layman, the appointment to take place at least six months before the delivery of said lecture.... The same lecture to be named and known as "the Ingersoll lecture on the Immortality of Man." 
